\title{
ANALISIS PERUBAHAN PENGGUNAAN LAHAN DI KECAMATAN PEKANBARU KOTA TAHUN 2007 DAN TAHUN 2014
}

\author{
Lusiana Anjulian', Ali Nurman² \\ 'Alumnus S1 Jurusan Pendidikan Geografi Fakultas IImu Sosial Universitas Negeri Medan \\ 2Jurusan Pendidikan Geografi Fakultas IImu Sosial Universitas Negeri Medan \\ Jl. Willem Iskandar Psr V Medan Estate Medan, 20211 Indonesia \\ Email: alinurman@unimed.ac.id
}

\begin{abstract}
Abstrak
Penelitian ini bertujuan untuk mengetahui (1) Perubahan Penggunaan Lahan di Kecamatan Pekanbaru Kota, (2) Faktor-faktor yang menyebabkan perubahan penggunaan lahan di kecamatan Pekanbaru Kota. Penelitian ini dilaksanakan di Kecamatan Pekanbaru Kota pada tahun 2016. Sampel dalam penelitian ini adalah seluruh kelurahan yang ada di Kecamatan Pekanbaru Kota atau total sampling. Penentuan sampel penggunaan lahan ditentukan menggunakan teknik Purposive random sampling. Teknik analisis data yang digunakan yaitu Sistem Informasi Geografi (Overlay) dan Deskriptif Kualitatif. Hasil penelitian ini menunjukkan bahwa: (1) Perubahan penggunaan lahan dalam jangka waktu 7 tahun (2007 dan 2014) tidak terlalu signifikan perubahan luas penggunaan yang terjadi di Kecamatan Pekanbaru Kota tahun 2007 dan tahun 2014 adalah 79,37 ha dari seluruh luas wilayah Kecamatan Pekanbaru kota. Penggunaan lahan yang mengalami perubahan paling banyak adalah lahan Pekarangan yaitu 32,5 ha. Selanjutnya disusul penambahan penggunaan lahan pertokoan sebanyak 8,41 ha, perkantoran 3,9 ha, dan hotel 0,24 ha.(2) Faktor-faktor yang menyebabkan penggunaan lahan yaitu faktor eksternal yang disebabkan adanya pertumbuhan ekonomi kota yang meningkat dan faktor daya dukung pemerintah dalam merancang perkotaan. Arah perubahan lahan saat ini mengarah kepada pembangunan perdagangan dan perhotelan, ini sesuai dengan rencana tata ruang kota pekanbaru yang memfokuskan bagi kecamatan Pekanbaru Kota menjadi wilayah perdagangan/pusat bisnis.
\end{abstract}

\section{Kata kunci: Perubahan Penggunaan Lahan, Qucikbird}

\section{PENDAHULUAN}

Sumber daya lahan yang terdapat pada suatu wilayah, pada dasarnya merupakan modal dasar pembangunan yang perlu digali dan dimanfaatkan dengan memperhatikan karakteristiknya. Karakteristik lahan yang kompleks membuat terjadi persaingan dalam penggunaan lahan untuk berbagai aktivitas. Secara ekonomis, persediaan lahan bersifat tetap, sedangkan permintaannya terus bertambah seiring dengan dinamika perkembangan wilayah. Pertumbuhan kebutuhan lahan didorong oleh pertambahan penduduk, pendapatan, dan tingkat migrasi penduduk yang berasal dari wilayah lain (Anwar dalam Sugiharto, 2010:127).
Perserikatan Bangsa-Bangsa memperkirakan lebih dari setengah penduduk dunia telah hidup di kota (2011) dan terus meningkat hingga Sekitar 70 persen dari 6,4 miliar populasi dunia akan hidup di perkotaan pada tahun 2050. Amerika Utara dan Selatan adalah wilayah yang paling cepat menuju perkotaan, dimana lebih dari 80 persen penduduk tinggal di kota, diikuti Eropa ( 70 persen ), Asia dan Afrika ( 40 persen ). Rata-rata populasi penduduk kota di asia 9,4 juta, Amerika Selatan 4,6 juta, Afrika 3,9 juta, Eropa 2,5, dan Amerika Utara 1,4 juta.Pertumbuhan penduduk tersebut umumnya terkonsentrasi di kota-kota besar di pulau-pulau tersebut.Menumpuknya penduduk di kawasan perkotaan ini akan menimbulkan tantangan dan peluang di 
bidang perumahan, kesehatan, pendidikan, transportasi, dan berbagai pelayanan publik. (Nirwono, 2013).

Sebagaimana dikemukakan oleh Soemarwoto (1985) bahwa, Perubahan yang terjadi pada lingkungan sosial budaya masyarakat akan menimbulkan tekanan penduduk terhadap kebutuhan akan lahan. Tekanan penduduk yang besar terhadap lahan ini diperbesar oleh bertambahnya luasnya lahan pertanian yang digunakan untuk keperluan lain, misalnya permukiman, jalan, dan pabrik. Lahan yang sering dialih fungsikan adalah lahan pertanian dan hutan yang dijadikan sebagai lahan permukiman. Akibat dari alih fungsi ini akan terjadi ketidakseimbangan alam, maupun ketidakseimbangan dalam kehidupan sosial. Misalnya lahan pertanian yang tadinya sebagai tumpuan masyarakat dalam mata pencaharian, sekarang sudah tidak bertumpu lagi pada pertanian.

Dikawasan

pinggiran, perkembangan kawasan perkotaan menyebabkan perubahan penggunaan dari lahan sawah (pertanian/non perkotaan) ke penggunaan perkotaan (terutama perumahan). Sementara dikawasan pusatdan kawasan transisi kota, persaingan antara kegiatan perkotaan menyebabkan perubahan penggunaan lahan dari perumahan ke non perumahan (perdagangan dan jasa/komersial). Kedua jenis perubahan penggunaan lahan atau pemanfaatan lahan di kawasan perkotaan ini sesungguhnya merupakan sesuatu yang lazim terutama di kota besar/kota raya (Iwan dan Melani, 2000).

Kota Pekanbaru merupakan 1 dari kota di Indonesia yang diprediksi akan terus tumbuh berkembang dan menjadi pilihan investasi di tahun 2015 selain Balikpapan, Manado. Kota Pekanbaru unggul karena kota ini merupakan rumah beberapa perusahaan Multinasional, terutama sektor minyak, gas dan perkebunan. Pertumbuhan ekonominya di atas 8 persen, memungkinkan daya konsumsi masyarakatnya bergerak dinamis. Oleh karena itu kebutuhan akan properti terutama hunian terus menunjukkan pertumbuhan.

Perkembangan Kota Pekanbaru yang semakin pesat ditandai dengan semakin meningkatnya perkembangan dan pertumbuhan serta dinamika kegiatan sosial ekonomi yang berlangsung, seperti semakin banyaknya pusat-pusat pelayanan jasa, sektor ekonomi, industri, transportasi, pendidikan, pariwisata, dan ditunjang dengan akses jalan yang semakin baik. Kota Pekanbaru sebagai ibukota Provinsi Riau mengalami laju perkembangan wilayah yang relatif pesat dan karenanya merupakan wilayah yang strategis. Hal tersebut antara lain dikarenakan kedudukannya sebagai pusat kegiatan wilayah (PKW) dalam rencana tata ruang wilayah nasional. Pesat dan beragamnya aktivitas kegiatan perekonomian serta pertambahan jumlah penduduk sebagaimana telah dikaji akan membawa konsekuensi dan pengaruh kepada beragamnya masalah yang dihadapi dan berkaitan dengan penggunaan lahan (Anonimus, 2000).

Pekanbaru Kota sebagai salah satu kecamatan diwilayah Kota Pekanbaru yang merupakan wilayah pusat kota dan pemerintahan di Kota Pekanbaru.Kecamatan Pekanbaru Kota merupakan salah satu dari 12 kecamatan di Kota Pekanbaru yang mempunyai cakupan wilayah administratif seluas $2,26 \mathrm{~km}^{2}$ atau 226 ha dengan jumlah penduduk 28.914 jiwa pada tahun 2013. Angka ini mengalami peningkatan sebesar 0.06 persen daritahun 2012. Kepadatan penduduknya mencapai $12.794 \mathrm{jiwa} / \mathrm{km}^{2}$, dengankelurahan terpadat adalah Kelurahan Tanah Datar sebesar 22.686 jiwa $/ \mathrm{km}^{2}$ (Kecamatan Pekanbaru Kota dalam angka, 2014).

Pertambahan jumlah penduduk dan perluasan wilayah terbangun suatu kota selalu di ikuti penurunan kualitas lingkungan. Sehingga perlu terus dipantau perkembangannya, karena seringkali pemanfaatan lahan tidak sesuai dengan peruntukkannya dan tidak memenuhi syarat. Proses penggunaan lahan yang 
dilakukan manusia dari waktu ke waktu terus mengalami perubahan seiring dengan perkembangan peradaban dan kebutuhan manusia. Semakin tinggi kebutuhan manusia akan semakin tinggi terhadap kebutuhan lahan. Seperti kebutuhan lahan untuk tempat tinggal dan lahan untuk fasilitas-fasilitas lain.Hal ini menjadi persoalan besar bagi perencana, pengelola kota maupun penduduk sendiri. Bagi para perencana dan pengelola kota dinamika pertumbuhan penduduk yang cepat dan tuntutan pengaturan penggunaan lahan kota yang terbatas tetapi selalu berubah mendatangkan pekerjaan tersendiri. Ketersediaan peta-petaaktual sebagai basis bagi perencanaan dan pengelolaan kotamerupakan suatu hal yang sangat penting. Peta actual penggunaan lahan merupakan salah satu jenis peta yang sangat penting untuk keperluan perencanaan, pemantauan, dan evaluasi.

Banyak lembaga di Indonesia yang membutuhkan informasi mengenai penggunaan lahan. Penggunaan survei terestris untuk keperluan itu banyak menghadapi kendala, terutama yang berkaitan dengan waktu dan biaya. Pemanfaatan foto udara telah sangat disadari besar manfaatnya, namun pemotretan ulang daerah yang sama untuk selang waktu yang pendek jelas sangat banyak menghabiskan biaya. Penggunaan citra satelit untuk pemantauan perubahan penggunaan lahan akan dapat mengatasi masalah pemutakhiran data, khususnya untuk wilayah yang perlu dipetakan pada skala 1: 50.000 atau yang lebih kecil. (Danoedoro, 2012:16). Citra satelit yang digunakan penulis dalam penelitian ini adalah, jenis citra satelit Quickbird tahun 2007 dan 2014. Citra digital ini memiliki resolusi spasial $0,61 \mathrm{~m}-2,4 \mathrm{~m}$ dan merupakan sumber yang sangat baik dalam pemanfaatan untuk studi lingkungan dan analisis perubahan penggunaan lahan, pertanian, dan kehutanan.

Kebutuhan akan fasilitas pengolahan proses citra digital yang sekaligus dilengkapi dengan fasilitas SIC telah membuka kemungkinan- kemungkinan baru dalam analisis data spasial. Sistem pengolahan citra satelit dapat memberikan masukan pada SIC berupa peta-peta tematik hasil ekstraksi informasi dari citra digital satelit. Di sisi lain, fasilitas analisis spasial dari SIGmampu mempertajam kemampuan analisis pengolahan citra, terutama dalam hal pemanfaatan data bantu untuk meningkatkanakurasi hasil klasifikasi multispektral (Jensen dalam Danoedoro, 2005:12). Pemilihan lokasi penelitian di kecamatan Pekanbaru Kota berdasarkan melihat adanya kecenderungan mengalami perubahan fungsi lahan dan beberapa faktor utama perubahan lahan yaitu faktor penduduk dan aspek kebijakan. Berangakat dari hal tersebut, peneliti tertarik untuk melakukan penelitian dengan memanfaatkan citra satelit multitemporal, yaitu citra satelit Quickbird dan SIC untuk Analisis Perubahan Penggunaan Lahan di Kecamatan Pekanbaru Kota tahun 2007 dan Tahun 2014.

Beberapa masalah yang berkaitan dengan perubahan penggunaan lahan di daerah Kecamatan Pekanbaru Kota yang dapat diidentifikasi adalah sebagai berikut :Terjadi perubahan penggunaan dan pemanfaatan lahan kota, Perubahan penggunaan lahan yang terjadi tidak dapat diketahui seberapa luas untuk tiap unit penggunaan lahan, serta faktor-faktor apa saja yang menjadi penyebab perubahan lahan di kecamatan Pekanbaru Kota, Kota Pekanbaru.

Berdasarkan perumusan masalah di atas maka tujuan penelitian ini adalah sebagai berikut: (1) Mengidentifikasi Perubahan penggunaan lahan di Kecamatan Pekanbaru Kota pada tahun 2007 dan Tahun 2014; (2) Menganalisis faktor-faktor yang menyebabkan perubahan penggunaan lahan di Kecamatan Pekanbaru Kota pada tahun 2007 dan Tahun 2014.

\section{METODE PENELITIAN}

Penelitian berlokasi di Kecamatan Pekanbaru Kota. Secara astronomis Kecamatan ini terletak antara $0^{\circ} 30^{\prime} 26$ " - 
0 32' 7,4" Lintang Utara dan 101 27' 28,85" - 101 27' 28,85" Bujur Timur. Kecamatan Pekanbaru Kota secara administratif terdiri dari 6 kelurahan, yaitu Kelurahan Simpang Empat, Kelurahan Sumahilang, Kelurahan Tanah Datar, Kelurahan Kota Baru, Kelurahan Sukaramai, dan Kelurahan Kota Tinggi, dengan jumlah penduduk 28.914 jiwa pada tahun 2013. Alasan pemilihan lokasi dikarenakan perkembangan kota yang semakin meningkat sehingga berpotensi terjadinya alih fungsi lahan di Kecamatan Pekanbaru Kota.

Populasi dalam penelitian ini adalah penggunaan lahan di Kecamatan Pekanbaru Kota. Sampel dalam penelitian ini adalah seluruh kelurahan yang ada di Kecamatan Pekanbaru Kota atau total sampling. Penentuan sampel penggunaan lahan ditentukan menggunakan teknik Purposive random sampling, yakni teknik pengambilan sampel secara acak namun disertai dengan oleh kriteria-kriteria tertentu. Kriteria yang digunakan dalam pengambilan titik sampel yaitu, mengambil titik penggunaan lahan berupa data citra Quickbird yang mengalami perubahan.

Menurut Arikunto (1998), variabel penelitian adalah objek penelitian yang bervariasi, atau apa yang menjadi titik perhatian suatu penelitian, maka yang menjadi variabel dalam penelitian ini adalah:

1) Perubahan luas dan jenis penggunaan lahan di kecamatan Pekanbaru kota.

2) Faktor yang menyebabkan perubahan lahan.

Alat yang digunakan dalam penelitian ini adalah:

- Perangkat komputer (hardware) dengan spesifikasi minimum pentium 4 dengan RAM 3 GB dan grafik 512 MB sehingga mampu bekerja dalam mendigitasi peta dengan baik.

- Perangkat lunak (softwareG/S) untuk mengolah data spasial: ArcGis 10.1 dan google Earth Pro 7.1.2.2019 untuk mengambil citra digital.

- Perangkat lunak pendukung:MS Office Tools 2007
- Printer yang digunakan untuk mencetak hasil kerja yang telah dilakukan di komputer dalam bentuk data analog (hardcopy).

- GPS (Global Positioning System) yang digunakan dalam kerja lapangan untuk menunjukkan posisi sehingga sesuai dengan titik yang telah ditentukan.

- Kamera digital yang digunakan untuk dokumentasi lapangan.

Bahan

- Citra satelit Quickbird hasil perekaman tahun 2007 dan tahun 2014.

- Peta Administrasi Kecamatan Pekanbaru Kota

Peta administrasi yang digunakan adalah peta batas administrasi Kecamatan Pekanbaru Kota yang diperoleh dari Kantor Camat Pekanbaru Kota.

- Data - data Sekunder

Data sekunder yaitu pendukung yang diperoleh dari pemerintah kota Pekanbaru seperti BAPPEDA, BPS, Kantor Camat, dan Instansi-instansi terkait sesuai dengan data yang dibutuhkan untuk mendukung penelitian.

Adapun teknik pengumpulan data pada penelitian meliputi beberapa tahapan yaitu sebagai berikut:

1. Dokumentasi

Data primer dalam penelitian ini adalah citra Quickbird perekaman tahun 2007 dan tahun 2014 untuk wilayah kecamatan pekanbaru kota yang diperoleh dari Google Earth Pro 7.1.2.2019.kemudian data tersebut diambil secara mosaik atau perpotong dengan ketinggian mata $500 \mathrm{~m}$, selanjutnya akan menjadi citra Quickbird dengan resolusi tinggi. Selanjutnya untuk data sekunder dapat diperoleh secara langsung melalui instansi-instansi pemerintahan di lokasi penelitian.

2. Interpretasi Citra

Kegiatan interpretasi adalah kegiatan mengolah data yang ada sehingga menghasilkan informasi yang 
baru. Kegiatan ini dilakukan dikomputer yang berupa interpretasi visual, dengan cara menginterpretasi atau mendigitasi citra untuk memisahkan objek-objek tertentu sehingga dapat menghasilkan peta. Klasifikasi penggunaan lahan kota yang dipakai dalam interpretasi yakni, sistem klasifikasi penggunaan lahan kota menurut Sutanto yang telah di modifikasi. Berdasarkan interpretasi citra dapat diketahui penggunaan lahan, dan luas penggunaan pada setiap tahun pemotretan, sehingga dari hasil interpretasi ini diperoleh dua peta tentatif penggunaan lahan (tahun 2007 dan tahun 2014). Hasil interpretasi ini berupa peta tentatif dan belum lengkap. Peta tentatif ini agar menjadi peta yang lengkap dan memiliki tingkat kepercayaan yang tinggi, perlu dilakukan cek lapangan.

3. Observasi

Observasi merupakan cara mengumpulkan data penelitian melalui pengamatan, pengcatatan, dan pengunjungan instansi untuk mendapatkan data yang dibutuhkan. Dari kegiatan observasi dapat diperoleh data yang mungkin tidak dapat diperoleh dari citra Quickbird sehingga peta hasil interpretasi dapat diperbaiki sesuai dengan data terbaru dan dapat menjadi peta aktual. Observasi dapat berfungsi mengumpulkan data untuk keperluan uji ketelitian interpretasi citra Quickbird wilayah kecamatan pekanbaru kota dengan mengambil titik sampel koordinat dari penggunaan lahan.Cara pengujian ketelitian hasil interpretasi dalam penelitian ini adalah merujuk pada Mather (2004), metode yang digunakan yakni akurasi secara sederhana dihitung sebagai jumlah total titik yang benar dibagi jumlah total titik yang terlibat, dikalikan 100\% (Danoedoro, 2012:331).

4. Wawancara

Wawancara bertujuan untuk melihat penggunaan lahan di daerah penelitian saat dilakukan cek lapangan kondisinya sesuai atau tidak sesuai dengan kenampakan yang ditunjukkan pada citra Quickbird. Wawancara dilakukan kepada penduduk yang berada di sekitar penggunaan lahan tersebut dan mengetahui riwayat penggunaan lahan tersebut.

Untuk lebih jelasnya dapat dilihat pada digram alir penelitian pada Gambar 1. berikut:

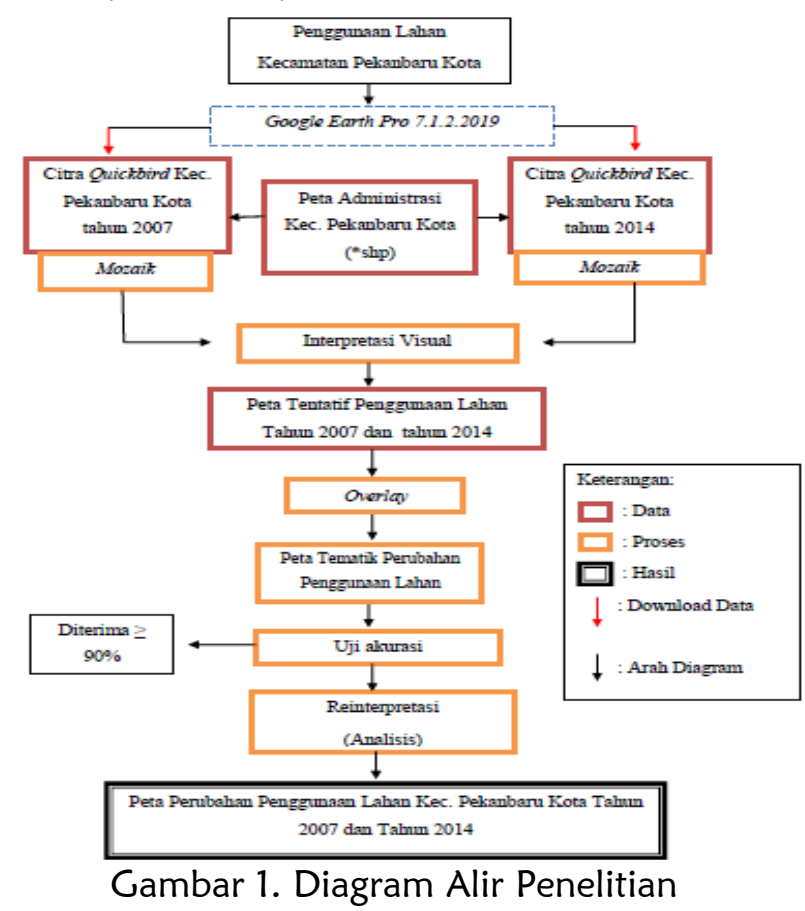


Teknik analisis data dalam penelitian ini adalah:

1. Analisis Sistem Informasi Geografi (Overlay)

Data yang akan dianalisis adalah data yang dperoleh dari hasil interpretasi citra, yaitu peta penggunaan lahan tahun 2007 dan tahun 2014, Kemudian data akan di analisis. Analisis pada tahap ini adalah kegiatan

Reinterpretasi (menginterpretasi ulang) peta dilakukan setelah melakukan uji ketelitian dan observasi. Dari proses reinterpretasi maka akan dihasilkan peta perubahan penggunaan lahan yang telah di-overlay (data tahun 2007 dan tahun 2014).

Analisis terhadap perubahan penggunaan lahan, luas masing-masing penggunaan lahan, luas $_{772000}$ perubahan,

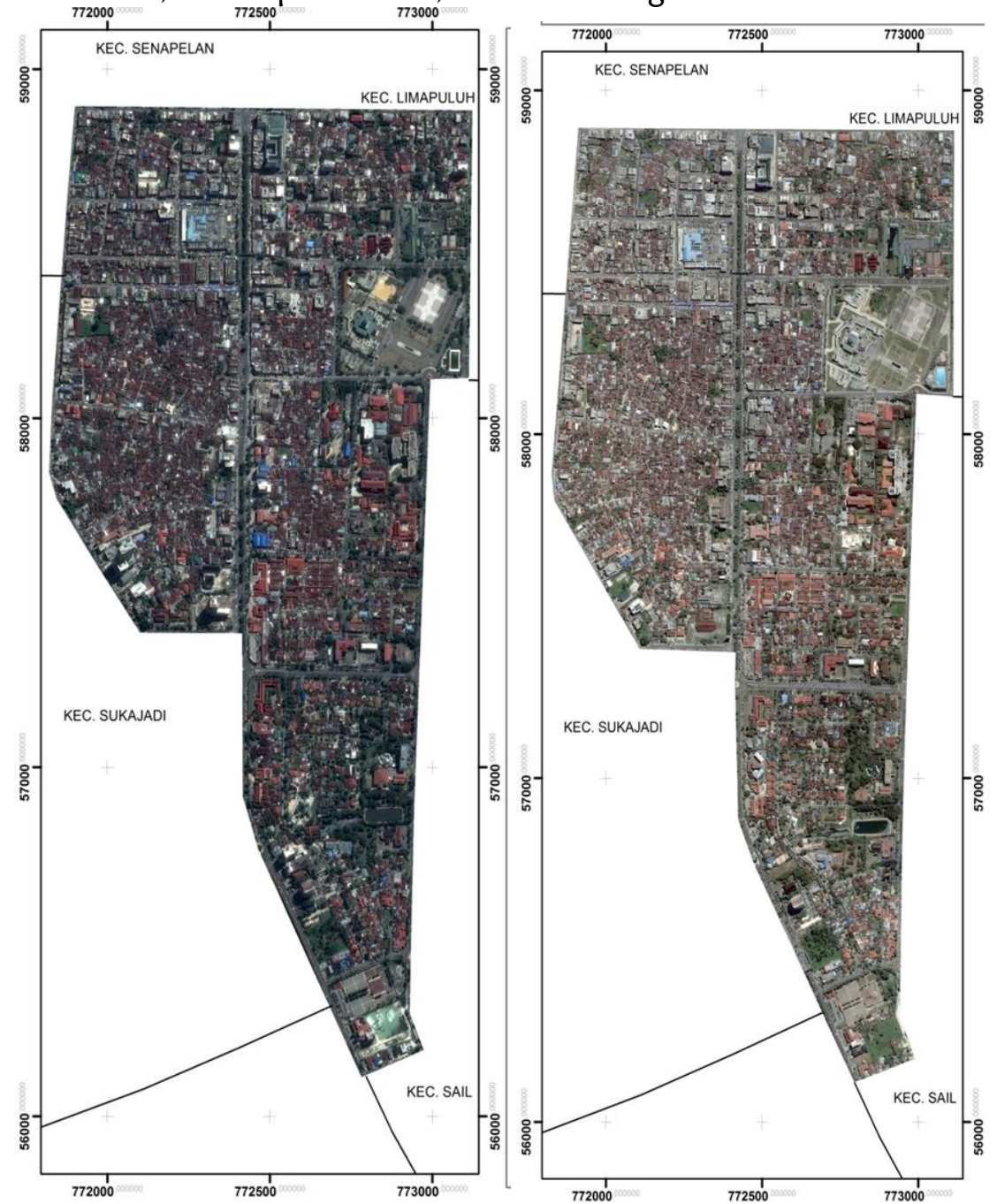

Gambar 2. Citra Quickbird 2007 dan 2014 dengan analisis sistem informasi geografis. Masing-masingdari peta penggunaan lahan yang berbeda waktunya ditumpangsusunkan dengan teknik Overlay, sehingga dapat diketahui perubahan jenis, luas, dan luas perubahan lahannya untuk menghasilkan informasi berupa peta perubahan penggunaan lahan di kecamatan Pekanbaru Kota sesuai.

2. Teknik Analisis Deskriptif Kualitatif Analisis deskriptif digunakan untuk menjelaskan hasil-hasil temuan di lapangan. Hasil temuan dari penelitian tersebut antara lain luas perubahan penggunaan lahan, jenis penggunaan lahan dan faktor-faktor yang penyebab perubahan penggunaan lahan berupa meliputi faktor eksternal, internal maupun regulasi. 


\section{HASIL DAN PEMBAHASAN}

\section{Perubahan Penggunaan Lahan}

Perubahan penggunaan lahan dalam kenyataannya begitu kompleks, sehingga untuk dapat mengetahui secara jelas mengenai perubahan tiap unit penggunaan lahan, berikut ini diuraikan kondisi penggunaan lahan dan perubahannya. Hasil interpretasi penggunaan lahan dari citra Quickbird tahun 2007 dan tahun 2014 yang telah di Overlay, menunjukkan bahwa penggunaan lahan di daerah penelitian semakin bervariatif dan kompleks, walaupun bila dilihat dari jumlah penggunaan lahan mengalami penurunan, terutama penggunaan lahan untuk permukiman. Penurunan jumlah penggunaan lahan permukiman itu bukan karena digunakan untuk penggunaan lahan lain. Fenomena lainnya adalah bertambahnya jumlah lahan perkantoran, perdagangan. Pemanfaatan lahan untuk permukiman menempati areal seluas 89,1 ha pada tahun 2007, menjadi 82,3 ha pada tahun 2014. Ini berarti ada pengurangan lahan permukiman sebanyak 6,8 ha atau $3,03 \%$.

Secara umum perkembangan penggunaan lahan untuk usaha/perdagangan ini di daerah penelitian memiliki persentase yang paling besar diantara penggunaan lahan lainnya. Untuk lebih jelas dapat dilihat di gambar 3 dan tabel 1 berikut ini.
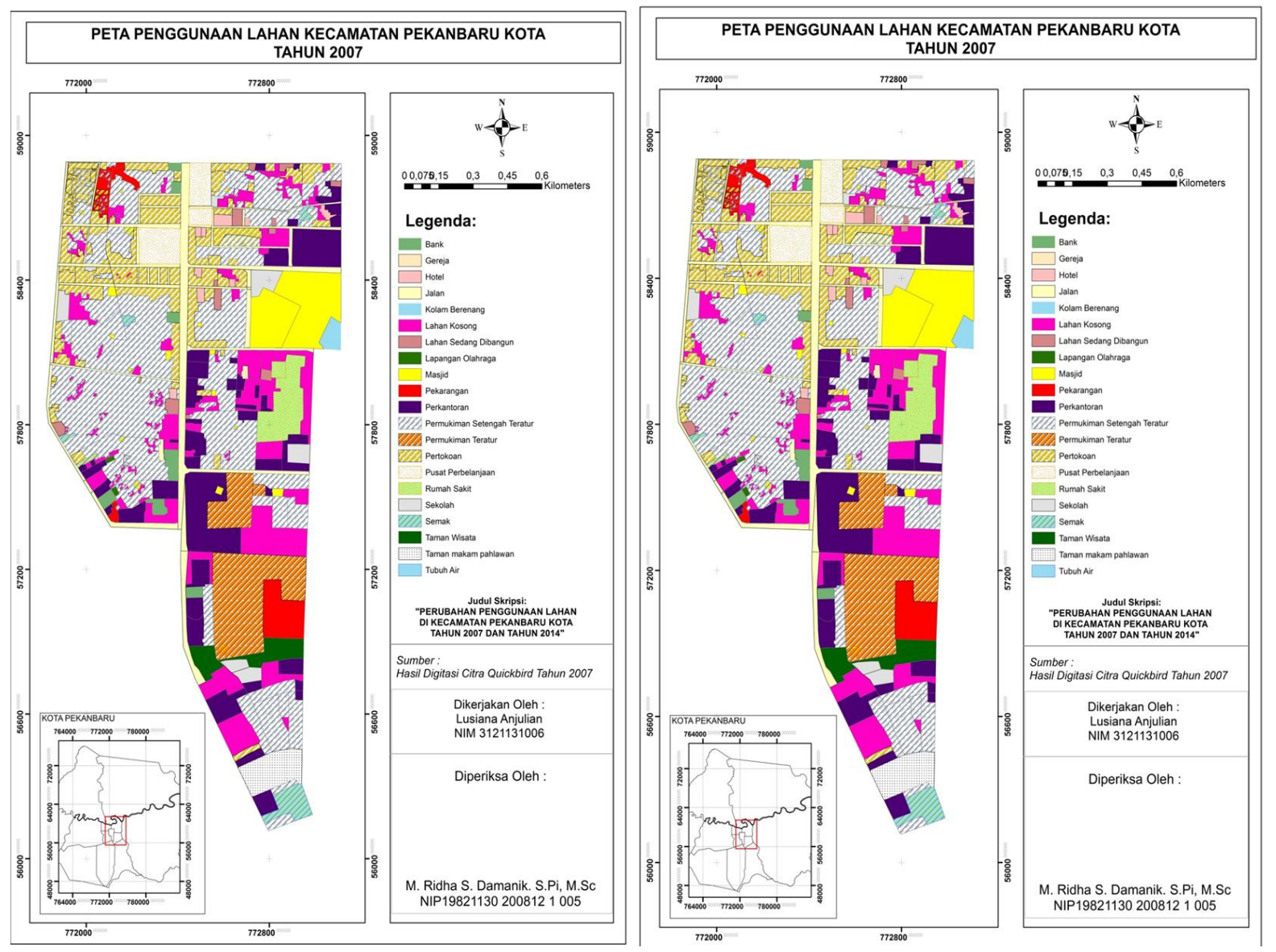

Gambar 3. Penggunaan Lahan Tahun 2007 dan 2014 
Tabel 1. Bentuk dan Luas Penggunaan Lahan Tahun 2007, 2014 dan Perubahannya.

\begin{tabular}{|c|c|c|c|c|}
\hline \multirow{2}{*}{ No } & \multirow{2}{*}{$\begin{array}{c}\text { Bentuk Penggunaan } \\
\text { Lahan }\end{array}$} & \multicolumn{2}{|c|}{ Luas $(\mathrm{Ha})$} & \multirow{2}{*}{$\begin{array}{l}\text { Perubahan } \\
\quad(\mathrm{Ha})\end{array}$} \\
\hline & & 2007 & 2014 & \\
\hline \multirow{4}{*}{1.} & Permukiman & - & - & - \\
\hline & a. Teratur & 15,81 & 15,81 & 0 \\
\hline & b. Setengah Teratur & 73,29 & 66,44 & $-6,85$ \\
\hline & c. Tidak Teratur & - & - & - \\
\hline \multirow{3}{*}{2.} & Perdagangan & - & - & - \\
\hline & a.Pertokoan & 21 & 29,41 & 8,41 \\
\hline & b. Pusat Perbelanjaan & 5,1 & 5,1 & 0 \\
\hline \multirow{7}{*}{3.} & Jasa Kelembagaan & - & - & - \\
\hline & a. Perkantoran & 27,61 & 31,51 & 3,9 \\
\hline & b. Kampus/Sekolah & 3,92 & 3,83 & 0 \\
\hline & c. Rumah Sakit & 5,22 & 5,22 & 0 \\
\hline & d. Bank & 2,49 & 2,49 & 0 \\
\hline & $\begin{array}{l}\text { Jasa Non- } \\
\text { Kelembagaan }\end{array}$ & - & - & - \\
\hline & a. Hotel & 1,93 & 2,17 & 0,24 \\
\hline 4. & Tempat Ibadah & 11,84 & 11,84 & 0 \\
\hline 5. & Transportasi (Jalan) & 10 & 10 & 0 \\
\hline \multirow{3}{*}{6.} & Rekreasi & - & - & - \\
\hline & a.Lapangan Olahraga & 0,53 & 0,42 & $-0,11$ \\
\hline & b. Kolam Berenang & 0,94 & 0,94 & 0 \\
\hline \multirow{2}{*}{7.} & Hutan/ Taman Wisata & - & - & - \\
\hline & b. Taman Wisata & 3,42 & 3,42 & 0 \\
\hline \multirow{8}{*}{8.} & Lain-lain & - & - & - \\
\hline & $\begin{array}{l}\text { a. Taman Makam } \\
\text { Pahlawan }\end{array}$ & 3,62 & 3,62 & 0 \\
\hline & b. Lahan kosong & 31,46 & 2,04 & $-29,42$ \\
\hline & $\begin{array}{l}\text { c. Lahan Sedang } \\
\text { Dibangun }\end{array}$ & 2,22 & 1 & $-1,22$ \\
\hline & d. Tubuh Air & 0,06 & 0,06 & 0 \\
\hline & Lahan Hijau & 5,53 & 32,71 & 27,18 \\
\hline & a. Semak & 2,38 & 2,04 & $-0,34$ \\
\hline & b. Pekarangan & 3,15 & 32,57 & 29,42 \\
\hline
\end{tabular}

Sumber: Hasil Interpretasi Citra Quickbird, Overlay dan Cek Lapangan Kecamatan Pekanbaru Kota.

Penggunaan lahan di Kecamatan Pekanbaru Kota tahun 2007 di dominasi Permukiman setengah teratur sebesar 73,29 Ha dan Lahan Kosong dengan luas 31,46 Ha. Proporsi Penggunaan Lahan Permukiman yang paling besar terdapat di Kecamanatan Tanah Datar untuk Permukiman setengah teratur dengan luas 20,2 ha, dan Kelurahan Simpang Empat untuk Permukiman Teratur sebesar 15,8 ha. Hal ini di karenakan kedua kecamatan tersebut memiliki jumlah penduduk yang cukup tinggi di Kecamatan Pekanbaru Kota Pada tahun 2007, yaitu sebesar 6.848 jiwa di kelurahan Tanah Datar dan 2.085 jiwa di Kelurahan Simpang Empat.

Penggunaan lahan pada tahun 2014 yang mengalami penurunan luas terbesar 
adalah lahan kosong. Penggunaan lahan ini mengalami penurunan sebesar 2,04 ha, diikuti dengan permukiman setengah teratur menjadi 66,44 ha dan lahan sedang dibangun mengalami penurunan menjadi 1 ha. Penurunan luas lahan kosong terbesar terjadi di Kelurahan Simpang Empat, yang sejalan dengan peningkatan luas untuk penggunaan lahan lahan hijau sebagai area ruang terbuka.

\section{Pola Perubahan Penggunaan Lahan tahun 2007 dan tahun 2014}

Dalam mengamati pola perubahan penggunaan lahan, hak yang perlu dicermati adalah perubahan menjadi penggunaan lahan apa dan penggunaan lahan sebelumnya. Perubahan penggunaan lahan dari tahun 2007 dan tahun 2014 disajikan dalam Tabel 1. Dalam tabel ini terlihat perubahan luas masing-masing penggunaan lahan tidak terlalu signifikan. Perubahan penggunaan lahan terbesar yaitu terjadi pada penggunaan lahan kosong menjadi lahan hijau, lahan kosong menjadi perkantoran, permukiman setengah teratur menjadi pertokoan dengan luas perubahan berturut-turut sebesar 29,1 ha, 2,3 ha dan 2,1 ha. Berikut ini akan diuraikan jenis perubahan penggunaan lahan dari tahun 2007 dan tahun 2014 secara rinci per Kelurahan di Kecamatan Pekanbaru Kota.

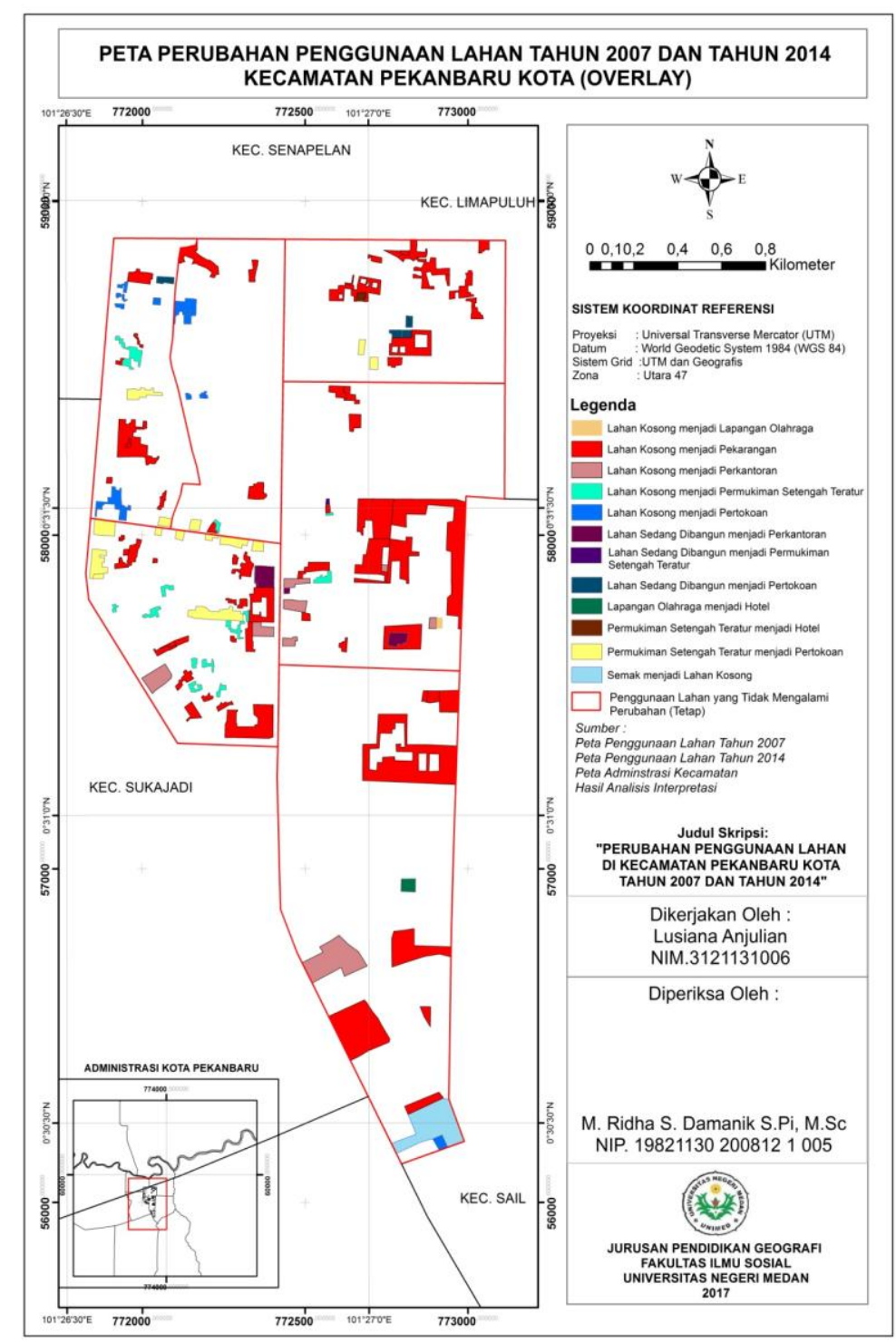

Gambar 4. Perubahan Penggunaan Lahan di Kecamatan Pekanbaru Kota 
Perubahan Penggunaan Lahan Permukiman Setengah Teratur

Dalam selang waktu 7 tahun telah terjadi perubahan penggunaan lahan permukiman setengah teratur menjadi hotel, lahan kosong, pertokoan. Perubahan ini terjadi di sebagian kelurahan di
Kecamatan Pekanbaru Kota, antara lain kelurahan Kota Tinggi, Kelurahan Kota Baru, Kelurahan Simpang Empat, dan Kelurahan Sukaramai. Luas perubahan permukiman setengah Teratur menjadi penggunaan lahan lain dapat dilihat pada tabel 2.

Tabel 2. Luas Perubahan Penggunaan Lahan Permukiman Setengah Teratur menjadi Penggunaan Lahan Lain (Ha) Tahun 2007 dan Tahun 2014

\begin{tabular}{|l|c|c|c|c|}
\hline \multirow{2}{*}{ Kelurahan } & \multicolumn{2}{|c|}{ Luas (Ha) Perubahan Permukiman Tidak Teratur } & $\begin{array}{c}\text { Luas } \\
\text { Perubahan } \\
\text { Per }\end{array}$ \\
\cline { 2 - 4 } & Hotel & Lahan Hijau & Pertokoan & $\begin{array}{c}\text { Kelurahan(ha) } \\
\text { Kota Baru }\end{array}$ Kota Tinggi \\
Simpang Empat & 0,06 & 0,26 & 1,6 & 1,86 \\
Sukaramai & & 0,20 & 0,4 & 0,46 \\
Sumahilang & & & 0,1 & 0,20 \\
Tanah Datar & & & & 0,1 \\
\hline Jumlah & 0,06 & 0,46 & 2,1 & 2,62 \\
\hline
\end{tabular}

Sumber: Hasil Interpretasi Citra Quickbird dan Cek Lapangan Kecamatan Pekanbaru Kota.

\begin{abstract}
Berdasarkan tabel diatas, Perubahan terbesar terjadi pada permukiman setengah teratur menjadi pertokoan sebesar 2,1 ha. Perkembangan Penggunaan lahan untuk perdagangan khususnya pertokoan ini sangat pesat meningat bahwa daerah ini (Jalan Sudirman) merupakan salah satu poros transportasi pusat kota.perkembangan daerah disekitar jalur transportasi ini sangat pesat dibandingkan daerah lain di wilayah kecamatan Pekanbaru Kota, kenyataan ini sesuai dengan teori poros yang dikemukakanoleh Babcock (1931 dalam Yunus, Hadi Sabari, 2000) yang menyatakan bahwa daerah yang dilalui jalur transportasi akan mempunyai perkembangan fisik yang berbeda diantara jalur transportasi ini. Demikian halnya yang terjadi di sepanjang jalan Soedirman yang merupakan jalur transportasi utama yang memungkinkan penjual dan pembeli
\end{abstract}

berinteraksi secara cepat karena aksesbilitas fisik jalur ini yang tinggi, sehingga daerah sepanjang jalan tersebut mempunyai tingkat perkembangan yang lebih tinggi dari daerah di sekitarnya. Hanya saja, untuk masa mendatang perlu dipikirkan alternatif pengelolaan agar di daerah ini tidak berkembang menjadi daerah pada yang kumuh.Perubahan ini dapat terjadi karena kebijakan pemerintah Kota Pekanbaru dalam meningkatkan perekonomian kota di khususkan untuk wilayah kecamatan Pekanbaru kota.

\section{Perubahan Pengunaan Lahan Sedang Dibangun}

Perubahan penggunaan lahan sedang dibangun menjadi penggunaan lahan lain per kelurahan disajikan pada tebel 3. Pada tahun 2007 dan tahun 2014 penggunaan lahan sedang dibangun telah mengalami konversi lahan menjadi perkantoran dan pertokoan. 
Tabel 3. Luas Perubahan Penggunaan Lahan Sedang Dibangun menjadi Penggunaan Lahan Lain (Ha) Tahun 2007 dan Tahun 2014

\begin{tabular}{|l|c|c|c|}
\hline \multirow{2}{*}{ Kelurahan } & \multicolumn{2}{|c|}{$\begin{array}{c}\text { Luas (Ha) Perubahan Lahan Sedang } \\
\text { Dibangun Menjadi }\end{array}$} & $\begin{array}{c}\text { Luas Perubahan } \\
\text { Per Kelurahan (ha) }\end{array}$ \\
\cline { 2 - 3 } & Perkantoran & Pertokoan & \\
\hline Kota Baru & & 0,20 & 0,20 \\
Kota Tinggi & & 0,50 & 0,50 \\
Simpang Empat & & & \\
Sukaramai & 0,8 & & 0,8 \\
Sumahilang & 0,3 & & 0,3 \\
Tanah Datar & 1,1 & 0,70 & 1,8 \\
\hline \multicolumn{1}{|c|}{ Jumlah } & & & \\
\hline
\end{tabular}

Sumber: Hasil Interpretasi Citra Quickbird dan Cek Lapangan Kecamatan Pekanbaru Kota.

\section{Perubahan Penggunaan Lahan Kosong}

Perubahan penggunaan lahan lahan kosong menjadi penggunaan lahan lain disajikan dalam tabel 4. Dalam jangka 7 tahun, penggunaan lahan kosong banyak berubah menjadi berbagai penggunaan lahan hijau, lapangan olahraga, perkantoran, permukiman setengah teratur, dan pertokoan.

Tabel 4. Luas Penggunaan Lahan Kosong menjadi Penggunaan Lahan Lain (Ha) tahun 2007 dan tahun 2014

\begin{tabular}{|c|c|c|c|c|c|c|}
\hline \multirow[b]{2}{*}{ Kelurahan } & \multicolumn{5}{|c|}{$\begin{array}{c}\text { Luas (Ha) Perubahan Lahan Kosong } \\
\text { Menjadi }\end{array}$} & \multirow{2}{*}{$\begin{array}{c}\text { Luas } \\
\text { Perubahan } \\
\text { Per } \\
\text { Kecamatan } \\
\text { (ha) }\end{array}$} \\
\hline & 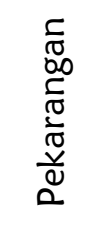 & 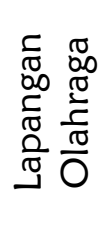 & 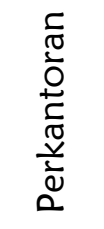 & 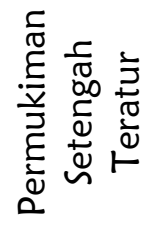 & $\begin{array}{l}\text { ̃ } \\
0 \\
0 \\
0 \\
0 \\
0 \\
0\end{array}$ & \\
\hline Kota Baru & 4,0 & & & 0,33 & 0,55 & 4,88 \\
\hline Kota Tinggi & 4,4 & 1,3 & & & 0,08 & 5,88 \\
\hline Simpang Empat & 6,5 & & 1,21 & & 0,11 & 7,72 \\
\hline Sukaramai & 1,1 & & & 0,03 & 0,46 & 1,59 \\
\hline Sumahilang & 5,6 & 0,19 & 0,65 & 0,01 & & 6,45 \\
\hline Tanah Datar & 5,4 & & 0,44 & 0,52 & & 6,36 \\
\hline Jumlah & 27,0 & 1,49 & 2,3 & 0,9 & 1,2 & 32,88 \\
\hline
\end{tabular}

Sumber: Hasil Interpretasi Citra Quickbird dan Cek Lapangan Kecamatan Pekanbaru Kota.

Tabel 4 menunjukkan perubahan lahan kosong terbesar yaitu menjadi lahan Pekarangan dengan luas 27,0 ha dan diikuti dengan perubahan menjadi perkantoran seluas 2,3 ha. Perubahan lahan kosong menjadi penggunaan lahan lain terjadi di seluruh Kelurahan. Kelurahan yang mengalami perubahan lahan kosong terbesar adalah kelurahan Simpang Empat sebesar 8,82 ha dengan perubahan yang mendominasi yaitu lahan hijau sebesar 7,5 ha. Perubahan lahan kosong menjadi Pekarangan terjadi karena adanya peningkatan kebutuhan ruang terbuka di daerah perkotaan khususnya di Kecamatan Pekanbaru Kota.

\section{Perubahan Penggunaan Lahan Lapangan Olahraga}

Penggunaan lahan lapangan olahraga termasuk salah satu lahan rekreasi yang berubah menjadi penggunaan lahan hotel. Untuk lebih detail di sajikan dalam tabel 5. 
Tabel 5. Luas Perubahan Lahan Lapangan Olahraga Tahun 2007 dan Tahun 2014

\begin{tabular}{|l|c|}
\hline Kelurahan & $\begin{array}{c}\text { Luas Perubahan Lahan Lapangan Olahraga Menjadi Hotel } \\
(\mathrm{Ha})\end{array}$ \\
\hline Kota Baru & 0 \\
Kota Tinggi & 0 \\
Simpang Empat & 0,70 \\
Sukaramai & 0 \\
Sumahilang & 0 \\
Tanah Datar & 0 \\
\hline \multicolumn{1}{|c|}{ Jumlah } & 0,70 \\
\hline
\end{tabular}

Sumber: Hasil Interpretasi Citra Quickbird dan Cek Lapangan Kecamatan Pekanbaru Kota.

Tabel 5. Menunjukkan total hasil perubahan lahan lapangan olahraga sebesar 0,70 ha. Perubahan ini terjadi karena adanya perluasan lahan untuk bangunan hotel yang terdapat di kelurahan Simpang Empat.

\section{Perubahan Penggunaan Lahan Semak}

Penggunaan lahan Semak termasuk salah satu lahan Hijau yang berubah menjadi lahan Kosong. Untuk lebih detail di sajikan dalam tabel 6 .

Tabel 6. Luas Perubahan Lahan Semak Tahun 2007 dan Tahun 2014

\begin{tabular}{|l|c|}
\hline Kelurahan & $\begin{array}{c}\text { Luas (Ha) Perubahan Lahan Lapangan Olahraga Menjadi } \\
\text { Lahan Kosong }\end{array}$ \\
\hline Kota Baru & 0 \\
Kota Tinggi & 0 \\
Simpang Empat & 2,04 \\
Sukaramai & 0 \\
Sumahilang & 0 \\
Tanah Datar & 0 \\
\hline \multicolumn{1}{|c|}{ Jumlah } & 2,04 \\
\hline
\end{tabular}

Sumber: Hasil Interpretasi Citra Quickbird dan Cek Lapangan Kecamatan Pekanbaru Kota.

Tabel 6 menunjukkan total hasil perubahan lahan Semak sebesar 2,04 ha. Perubahan ini terjadi karena adanya perluasan lahan Kosong yang belum rencanakan tujuan dari lahan tersebut. Lahan ini terdapat di kelurahan Simpang Empat.

\section{KESIMPULAN DAN SARAN}

\section{Kesimpulan}

1. Perubahan penggunaan lahan di Kecamatan Pekanbaru Kota dalam jangka waktu 7 tahun (2007 dan 2014) merupakan perubahan yang tidak terlalu signifikan perubahan luas penggunaan yang terjadi di Kecamatan Pekanbaru Kota tahun 2007 dan tahun 2014 adalah 79,37 ha dari seluruh luas wilayah Kecamatan Pekanbaru kota. Penggunaan lahan yang mengalami perubahan paling banyak adalah Pekarangan yaitu 32,5 ha. Selanjutnya disusul penambahan penggunaan lahan pertokoan sebanyak 8,41 ha, perkantoran 3,9 ha, dan hotel 0,24 ha.

2. Perubahan yang tidak terlalu terlihat ini dapat dipengaruhi karena pembangunan di kecamatan Pekanbaru Kota telah direncanakan sesuai dengan RUTR Kota Pekanbaru tahun 1994-2004. Faktor-faktor yang menyebabkan penggunaan lahan di Kecamatan Pekanbaru Kota yaitu faktor eksternal yang disebabkan adanya pertumbuhan ekonomi kota yang meningkat lebih dari 8\% (2015) dan faktor daya dukung pemerintah dalam merancang perkotaan yang terencana. Terlihat arah perubahan lahan saat ini mengarah kepada pembangunan perdagangan dan perhotelan, ini sesuai dengan rencana 
tata ruang kota pekanbaru yang memfokuskan bagi kecamatan Pekanbaru Kota menjadi wilayah perdagangan/pusat bisnis.

\section{Saran}

1. Penggunaan lahan pertokoan yang bertambah sebanyak 8,41 ha atau 3,71 $\%$ dari luas wilayah di sepanjang jalan penghubung pusat perkotaan, dapat menyebabkan terjadinya permasalahan baru seperti kemacetan karena adanya lahan parkir di sepanjang jalan pertokoan. Perlu adanya penanganan ketertiban disekitar lahan pertokoan agar tidak terjadi kemacetan yang merayap.

2. Pembangunan yang stabil dan terencana di Kecamatan Pekanbaru Kota merupakan salah satu kecamatan di Kota Pekanbaru dapat menjadi wilayah per contohan untuk wilayah lain dalam masa pembangunan agar dapat menjadi wilayah yang berkelanjutan.

3.

\section{DAFTAR PUSTAKA}

Anonimus. 2015. Tipologi Konversi Dan Arahan Pengendaliannya Di Kota Pekanbaru, (Online), (http://repoitory.unri.ac.id/ diakses 07 Mei 2016).

Berutu, Doni Saputra. 2012. Aplikasi Penginderaan Jauh dan Sistem Informasi Geografis dalam Mengkaji Perubahan Luas Hutan di Kabupaten Kuantan Singingi (RIAU) Tahun 2000-2010. Skripsi (Tidak Diterbitkan). Medan: Jurusan Pendidikan Geografi Fakultas IImu Sosial Univeritas Negeri Medan

Branch, Melville C. 1995. Perencanaan Kota Komprehensif: Pengantar dan Penjelasan. Yogyakarya: Gadjah Mada University Press

Danoedoro, Projo. 2012. Pengantar Penginderaan Jauh. Yogyakarta: Andi
Howard, J. A. 1996. Penginderaan Jauh Untuk Sunberdaya Hutan: Teori dan Aplikasi. (Diterjemahkan oleh $\mathrm{R}$. Dubahri). Yogyakarta: Gadjah Mada Unniversity Press

Hsaidaturramah, Nurul. 2015. Penggunaan Lahan Perkotaan.

(http://nurulhsaidaturramah.blogspot .com/2015/05/Penggunaan-LahanPerkotaan.html) diakses pada 1 April 2016, 15.50 WIB

Joga, Nirwono. 2007. Gerakan Kota Hijau. Jakarta: Gramedia Pustaka Utama.

Kustiwan, Iwan., dan Anugrahani, Melani. 2000. Perubahan Pemanfaatan Lahan Perumahan Ke Perkantoran: Implikasinya Terhadap Pengendalian Pemanfaatan Ruang Kota (Studi Kasus: Wilayah Pengembangan Cibeunying Kota Bandung).Jurusan Perencanaan Wilayah dan Kota. Vol. 11. No.1/Juni 2000

Lillesand, T. M., Kiefer, R.W. 1999. Penginderaan Jauh dan Interpretasi Citra (diterjemahkan oleh Sutanto). Yogyakarta: Gadjah Mada Unniversity Press

Leonataris, Citra. 2012. Analisis Perubahan Penggunaan Lahan Dan Perkembangan Wilayah di Kota Bekasi. Skripsi. Jurusan Manajemen Sumberdaya Lahan: Institut Pertanian Bogor (repository.ipb.ac.id/handle/1234567 89/54893) diakses pada 26 Agustus 2016, 08.56 WIB

Lestari, W., \& Simanungkalit, N. M. (2012). Analisis Perubahan Penggunaan Lahan Wilayah Pesisir Desa Tanjung Rejo Kecamatan Percut Sei Tuan Kabupaten Deli Serdang (19902011). Jurnal Geografi, 4(2), 57-68.

Lo, C.P. 1995. Pengideraan Jauh Terapan (diterjemahkan oleh Bambang Purbowaseso). UI Press 
Lubis, D. P., \& Sitorus, N. (2012). Analisis Spasial yang Mempengaruhi Perkembangan Kecamatan Ujung Padang Kabupaten Simalungun Tahun 2005-2010. JURNAL GEOGRAFI, 4(2), 1-14.

Lumbantoruan, W. (2010). Studi Perkembangan Kota Medan Menggunakan Data Penginderaan Jauh Dan SIG. JURNAL GEOGRAFI, 2(2), 93-106.

Muta'ali, Lutfi. 2013. Penataan Ruang Wilayah dan Kota (Tinjauan Normatif-Teknis).Yogyakarta: Badan Penerbit Fakultas Geografi-UGM.

Purwantoro, Suhadi dan Hadi, B. Saiful. 2000. Studi Perubahan Studi Perubahan Penggunaan Lahan di Kecamatan Umbulharjo Kota Yogyakarta Tahun 1987-1996 Berdasarkan Foto Udara. Universitas Negeri Yogyakarta. Staff.uny.ac.id/sites/default/files

Peraturan Menteri Pekerjaan Umum Nomor : 05/PRT/M/2008 tentang pedoman penyediaan dan pemanfaatan ruang terbuka hijau di kawasan perkotaan, 2008. h. 2

Ridho, Cuzein. 2015. Pembangunan Kota Pekanbaru Tahun 2015. (http:// cuzeinridho.blogspot.com/2015/02/p embangunan-kota-pekanbaru-tahun2015.html) diakses pada 1 April 2016, 16.05 WIB

Sugiharto, 2006. Pembangunan dan Pengembangan Wilayah. Medan: USU Press
Susanti, Nazaria. 2014. Analisa Peubahan Penggunaan Lahan di Kecamatan Medan Johor tahun 2008-2013. Skripsi (Tidak Diterbitkan). Medan: Jurusan Pendidikan Geografi Fakultas Ilmu Sosial Univeritas Negeri Medan

Syahrir. 2010. Kajian Perubahan Pemanfatan Lahan Perumahan Menjadi Perdagangan dan Jasa Komersial di Perumahan Tumbuh I dan Perumahan Tumbuh II Kota Kendari. Thesis. Semarang: Universitas Diponogoro

Tri, Ewin. 2015. Perubahan Penggunaan Lahan.

(http://ewintribengkulu.blogspot.co m/2015/Perubahan-PenggunaanLahan.html) diakses pada 1 April 2016, 15.10 WIB

Wicaksono, Tangguh dan Sugiyanto, FX. 2014. Journal: Analisis Faktor-Faktor Yang Mempengaruhi Perubahan Pemanfaatan Perumahan Untuk Tujuan Komersial Di Kawasan Tlogosari Kulon, Semarang. Diakses 29 febriaru 2016

Yunus, Hadi Sabari. 2000. Struktur Tata Ruang Kota, Yogyakarta: Pustaka Pelajar

Zamroh, M. Rifky Abu. 2014. Analisis Perubahan Penggunaan Lahan Untuk Permukiman Di Kecamatan Kaliwungu Dengan Sistem Informasi Geografis. Jurusan Pendidikan Geografi IKIP Veteran Semarang. Vol. 2 No. 1 Oktober 2014 